\title{
Byelorussian Chronicle 1973
}

\section{EVENTS IN BYELORUSSIA}

A conference on the subject 'Typology and interrelations of Slavonic languages and literatures' was held in May at the Byelorussian State University in Minsk.

$$
\text { * }
$$

'Regional characteristics of Byelorussian language, literature and folklore' was the subject of the conference held in May at the University of Homiel.

$$
\text { * }
$$

In June the Janka Kupała Institute of Literature of the Byelorussian Academy of Sciences held a seminar on the problems of the development of Byelorussian literature in the 1920s and $30 \mathrm{~s}$.

A symposium of translators of works of Byelorussian literature into the languages of the peoples of the USSR took place in October in Minsk.

A conference 'The Origin of the Byelorussian Nation' took place in December at the Institute of Ethnography of the Byelorussian Academy of Sciences in Minsk.

A seminar of young writers, artists and scientists was held in September at the holiday camp 'Bryhancina' near Maładečna. There were 165 participants.

The director of the Byelorussian State Choir, Ryhor Syrma, and the poet Piatruś Broŭka, were awarded the Bulgarian Order of Cyril and Methodius.

The President of the Byelorussian Academy of Sciences, M. Barysevič, was awarded the Copernicus Medal by the Polish Academy of Sciences.

$$
*
$$

The poet Pimien Pančanka was awarded the title of 'People's Poet of Byelorussia'.

A festival of ${ }^{*}$ Soviet professional singers and instrumental musical ensembles took place in June in
Minsk. The first prize in the category of instrumental groups was won by the Byelorussian group 'Pieśniary'.

$$
\text { * }
$$

The Theatre of Musical Comedy in Minsk staged the premiere of the new operetta Paŭlinka by Jury Siemianiaka (libretto by Aleś Bačyła), based on the famous play of the same name by Janka Kupała.

Another adaptation of Kupała's Paŭlinka was the musical Paśla kirmašu (words by Andrej Makajonak, music by Jaŭhień Hlebaŭ) which was shown by Byelorussian television for the first time.

The Janka Kupała Theatre in Minsk staged the premiere of the new comedy Tabletku pad jazyk by Andrej Makajonak.

The new comedy Amazonki by Anatol Dzialendzik was produced by the Homiel theatre.

The Poetry Festival at Viazynka, Janka Kupała's native village, was held on 7th July. Apart from the several Byelorussian poets who took part in it (P. Broŭka, A. Bialevič, R. Baradulin, E. Ahniacviet, H. Buraŭkin, K. Cvirka, P. Makal, Uł. Paŭłaŭ, E. Łoś, Ja. Sipakoŭ, A. Viarcinski, A. Zarycki, and others) there were many other guests from Russia, Ukraine, Lithuania, Latvia and other countries.

The largest treasure of Arab dirhems in the USSR, consisting of about 8000 coins, was found by two schoolboys near the village of Kaźjanki in the district of Polack. The coins are from the 8th and 9th centuries and come from Baghdad, Samarkand, Bokhara and other places mainly in Central Asia.

$$
*
$$

The town of Rahačoŭ in SouthEastern Byelorussia was first mentioned in the chronicles under the year 1142. The results of an archaeological expedition, organised jointly by the universities of Homiel and 
Minsk show, however, that its origins should be taken further back to at least the beginnings of the 11th century.

\section{$*$}

The restoration of the famous 13th century keep 'Biełaja vieža' in Kamianiec in the Brest province has been completed. The keep is 20 metres high, has 5 floors and its walls are $2 \mathrm{~m}$. $30 \mathrm{~cm}$. thick. It will house a local historical and ethnographical museum.

\section{*}

The ethnographical expedition of the Byelorussian Academy of Sciences worked all summer in the Babrujsk and Asipovicy districts of the Mahiloŭ province and Puchavičy district of the Minsk province. Altogether 12 villages were visited and 2000 new items of folklore recorded. The interesting point noted was that many traditional and hitherto unknown folk songs were recorded from young people, which seems to indicate that traditional folklore is still very much alive despite the changing social conditions in the modern Byelorussian village.

An interesting reed-pipe ensemble exists in the village of Hałoǔšycy in Homiel province. It was formed by a

\section{EVENTS ABROAD}

A seminar on Byelorussian folklore of the Bielastok region was held in March at the University of Warsaw. Among the papers read were: 'Byelorussian folksongs in Federowski's Lud Biatoruski' by A. Barščeŭski; 'Byelorussian dialects of the Bielastok region' by $\mathrm{E}$. Smulkowa; and 'Children's folklore' by V. Sved.

Days of Byelorussian culture in Poland were held from 30th June to 7 th July. They were marked by special events in Warsaw, Biełastok and other places, among them concerts by Byelorussian artists, showing Byelorussian films, and exhibitions of Byelorussian art, books, etc.

At a conference commemorating the 150th anniversary of the birth of the Polish poet Władisław Syrokomla, a native of Byelorussia, held in June in Inowrocław and Torun, the following papers were read by Byelorussian teacher of the local school, Fiodar Malinoŭski, and among its members are his daughter Valancina and sonin-law Alaksandr Dorman, as well as some of his pupils. The repertoire of the ensemble consists of traditional Byelorussian folk tunes. It is wellknown outside Hałoŭčny, both in Byelorussia and in the neighbouring districts of the Ukraine.$$
\text { * }
$$

A folk-weaving circle, the only one in the country, exists at the Minsk Palace of Pioneers. Its members are recruited from among schoolchildren who learn the art of weaving traditional Byelorussian folk patterns.

*

One of the latest Soviet cosmonauts, IMaj. Piotr Klimuk, who made the flight in the spacehip 'Sojuz 13' in December, is a Byelorussian. He was born in 1942 in the village of Kamaroŭka in Brest province, where his mother and other members of his family still live.

The famous Byelorussian actor Uładzimir Dziadziuška died on 30th March. He was born in 1905. Practically all his professional career he was associated with the Janka Kupała Theatre in Minsk.

participants: A. Maldzis, 'Syrokomla and Byelorussian literature'; Uł. Marchiel, 'Byelorussian translations of Syrokomla's works': and K. Cvirka, Syrokomla as ethnographer'.

$$
\text { * }
$$

At the VII International Congress of Slavists in Warsaw in August the following papers were presented by Byelorussian scholars: H. Bartaševič, K. Kabašnikaŭ, 'The present-day state of Byelorussian folklore'; M. Biryła, V. Lemciuhova, 'Onomastic word-forming elements in East and West Slavonic languages'; V. Bandarčyk, L. Małaš, 'Byelorussian ethnography and folklore in the works of Slavonic scholars from the period of romanticism'; V. Cekman, 'Genesis and evolution of the palatal row in Palaeoslavic'; Uł. Kazbiaruk, 'Traditions of Polish romanticism in the Byelorussian literature of the early 20th century'; A. Maldzis, 'Traditions of Polish enlightenment in the Byelo- 
russian literature of the 19th century'; V. Martynaŭ, 'Palaeoslavic and Balto-Slavic suffix name derivation'; A. Suprun, 'Lexical combination in the Polabian language'; A. Žuraŭski, I. Kramko, 'Character of relations of the Byelorussian literary language with other Slavonic languages during the initial period of its formation'. In addition to this, A. McMillin (London) read a paper entitled 'Foreign elements in the abstract vocabulary of V. I. Dunin-Marcinkievič', and $H$. Bieder (Salzburg), "The Lithuania Statute of 1529 (notes on the historical orthography and phonetics of early Byelorussian official language)'. Papers by E. Smułkowa (Warsaw), F. Nieuwažny (Warsaw), K. Gutschmidt (Berlin) and a few others also dealt to a large extent with Byelorussian material.

The 'Wegierki' Theatre in Biełastok produced the play Trybunat by the Byelorussian playwright Andrej Makajonak. The play met with considerable success, both in Biełastok, and later in Torun and Katowice, when the theatre visited those cities. On the whole, Makajonak's Trybunat enjoys great popularity outside Byelorussia. It was produced in Sofia, Bulgaria, in Charkiv, Ukraine, and in the Malaja Bronnaja Thea'tre in Moscow. The Moscow Theatre of Satire produced the premiere of Makajonak's new comedy Tabletku pad jazyk a few months before it was staged in Byelorussia.

$$
\text { * }
$$

A memorial to Janka Kupała was unveiled at Arrow Park near New York on 1st July. At the unveiling ceremony the sculptor, A. Anikiejčyk, and the playwright A. Makajonak from Minsk were present.

An exhibition to mark the 90th anniversary of the birth of Janka Kupała and Jakub Kolas was held at the New York Public Library from 1 March to 15 May.

Another Byelorussian exhibition on the Statute of the Grand Duchy of Lithuania took place at the same library from 15 December, 1973 to 27 February, 1974.

A symposium ${ }^{*}$ on Byelorussian emigré literature was held at Queens College of the New York City University. The following papers were read: V. Kipiel, 'Belorussica in American Libraries'; A. Adamovič, 'V. Łastoŭski'; U. Siadura, 'Byelorussian theatre in emigration'; J. Zaprudnik, 'Ryhor Krušyna'; J. Sadoŭski, 'Byelorussian emigré writers in Canada'; and Z. Jurjeva, 'Poetry of Masiej Siadnioŭ'.

On the initiative of the Byelorussian Institute of Arts and Sciences, an exhibition of works of Byelorussian artists abroad was held in New York from 9 December, 1973 to 3 February, 1974. Altogether 19 artists exhibited their works, among them the sculptor M. Naumovič, the painters Uł. Symaniec, Ivonne Surviła, Iryna Rahalevič, Halina Rusak, J. Kaźlakoŭski and others.$$
\text { * }
$$

A doctoral thesis on the history of literary links between Georgia and Byelorussia has been written at Tbilisi University. The author, K. Kvachiankaradze, collected much interesting material, such as that on early translations into Georgian of works of the 12th century Byelorussian ecclesiastical writer St. Cyril of Turaŭ, and on the sojourn in Georgia of the 19th century Byelorussian poets F. Savič and J. Łučyna. Special chapters are devoted to the theme of Georgia in modern Byelorussian literature, and to the translation into Byelorussian of the poem Knight in a tiger skin by Shota Rustaveli.

At the eighth course of lectures on Byelorussian culture, organised in London by the Anglo-Byelorussian Society, during the academic year 1973-74 the following papers were read: G. Picarda, "The origins of contemporary graphic art'; H. Leeming, 'The language of the Kucieina Novy Zavet (1652)'; A. Nadson, 'Byelorussian prayer-books for laymen in the 16th and 17th cen'turies'; R. Sussex, "Transformational grammar and Byelorussian linguistics'; J. Dingley, 'The poet Aleś Harun'; R. A. French, "The development of urbanisation in Byelorussia'. 